\title{
Changes in Consumption of Households during 1990-1997*
}

\author{
MARTIN LUX \\ Institute of Sociology, Academy of Sciences of the Czech Republic, Prague
}

\begin{abstract}
The article provides social statistics concerning the main changes in the consumption behaviour of Czech households between 1990 and 1997. The description is based on a comparison with the situation and trends in countries of the European Union. The author uses the Family Budget Surveys data files that were weighted to assure higher representativeness of the research results. Different statistical procedures are employed to describe main shifts in the composition of household budgets on the whole and for different consumption items in the first stage, and according to different factors characterising the household in the second stage. In the last part of the article, multiple regression and ANOVA analysis were applied to answer the question of the changes in the influence of different social indicators of households on the relative household expenditures. The author cannot confirm the hypothesis that 'meritocratic' factors (income, education) have strengthened and 'demographic' factors (family size, age or residence size) have weakened in influence for explaining the variability of four basic relative consumer items. The changes in consumption behaviour have a transitional character rather than the character of long-term historical changes apparent in the countries of the European Union.
\end{abstract}

Czech Sociological Review, 2000, Vol. 8 (No. 2: 211-232)

\section{Introduction}

There are two main approaches forming the methodological background of a consumer behaviour analysis: the approach of econometrics and economics on the one hand, and the approach of sociology and social statistics on the other. The path of econometrics remains rather more theoretical than empirical; it is based on neo-classical assumptions of rational utility imperatives in human action and there is no (or only a small) place for a statistical analysis of real professional, gender, family size and other demographic cleavages. Moreover, a further assumption often plays an important role: the permanent and nonproblematic development of a society and its economy. In the case of the wide economic reforms currently underway in Eastern European countries, there are many more 'political' factors influencing individual and household consumer behaviour than in a standard Western democracy (deregulations, new tax structure, etc.). The housing expenditures and their share in the family budgets of Czech households are effects of the liberalisation of rents and energies and the continuous rigidity in the regulated rental sector rather than

\footnotetext{
*) This work was supported by the Research Support Scheme of the Open Society Support Foundation, grant No. 208/1999.

**) Direct all correspondence to: Ing. Mgr. Martin Lux, Institute of Sociology, Academy of Sciences of the Czech Republic, Jilská 1, 11000 Praha 1, phone +420 22222 0099, ext. 222 or 223, fax +420222220143, e-mail lux@soc.cas.cz
} 
effects of life-cycle assumptions ${ }^{1}$ or purely economic factors (inflation and interest rate changes).

Therefore, the approach of a complete statistical analysis of the main structural shifts in household consumption, along with a sociological interpretation, seems to be much more appropriate for an analysis of the consumer changes during the transition of Czech society. As we would like to stress the comparative aspect of the description, the first question of interest is: Is the structure of Czech household budgets closer to or further from the consumer patterns of European households after seven years of transition? Table 1 shows the structure of household consumption in the EU countries in 1993. According to Pouquet and Maincent [1999], who analysed empirical trends in consumption behaviour of households in Germany, France, Italy and the United Kingdom, there was the following development in relative expenditures ${ }^{2}$ from 1970 to 1996:

- Convergence of all countries in the case of relative 'food, beverage and tobacco' expenditures that are derogating (in Italy very sharply) with the economic development of the country;

- A growth in relative housing expenditures, but with no sign of convergence; this is due to the wide housing reforms in the European countries that had, however, different timing and different governmental goals;

- A growth in relative 'transport and communication' expenditures that is apparent mainly in more developed European countries;

- A diminution in relative 'clothing and footwear' expenditures; here also there is no convergence trend, because of different cultural traditions.

Are the changes in the Czech consumption patterns similar or completely different? How have Czech households compensated for the economic reform burden in their budgets? What were the main shifts in the structure of household budgets caused by the liberalisation of food and energy prices? What were the main social determinants of this change? Is there a shift towards more 'meritocratic' factors explaining the variability of relative household expenditures?

\section{Data and Methodology}

The Family Budget Surveys 1990-1997 (FBS's) provide us with a basic data source for an analysis of change in consumer behaviour. FBS was established in 1958 as a quota sample-based survey of households and it is conducted on a roughly $0.1 \%$ sample. The main quotas currently form the following social categories: manual workers, employees, cooperative farmers, pensioners and entrepreneurs. The survey is based on the daily records of all income and expenditures of sample households. Its realisation, however, is marked

\footnotetext{
1) In the EU countries, it is a common fact that young households start out by living in the rental sector (private or social) and only the higher income part of 'older' households can afford to buy a house or a flat into their ownership. Owner-occupation is a kind of luxury good, and if not (e.g. thanks to the 'Right to Buy' policy in Great Britain) then it is still quite an expensive adventure: owners are obliged not only to repay mortgage loans but also to cover all necessary maintenance costs of their home, which is not the case of families living in social rental flats.

2) Relative expenditures are defined as an average share of the monthly household expenditures of a specific kind (food, culture, clothing, etc.) out of the total monthly household expenditures. 
by some methodological and statistical defects: the lowest income households are underrepresented in research samples, the arrangement of consumer items does not correspond to the Eurostat standardisation hitherto, and the definitions of housing expenditure items do not separate the expenditures on primary housing from the expenditures on secondary housing (secondary housing is very popular in the Czech environment and pivotal for its analysis). The FBS data files were therefore weighted for the above mentioned social categories according to the representative survey Microcensus 1992 (FBS 1990 to FBS 1995) and Microcensus 1996 (FBS 1996 and 1997). The FBS 1996 was further weighted according to Microcensus 1996 by the control variables: age of head of household (HH), economic activity of $\mathrm{HH}$, sex of $\mathrm{HH}$, completed education of $\mathrm{HH}$, and the region of the household residence ( 8 regions). The differences in results between the first and the second file weighting were very marginal and therefore we worked with FBS's 1990-1997, weighted simply for main quotas.

A wide scale of statistical procedures has provided a statistical comparison of consumer patterns 'in time and space'. To identify major trends and changes, the multiple comparison procedures (Scheffé and Duncan testing of means), the multiple regression analysis and the multiple ANOVA analysis were used. ANOVA analysis (an analysis of variance) tests the hypothesis that the group means of the dependent variable are equal. In multiple classification analysis (forming a part of ANOVA syntax) the $\eta$ and $\beta$ coefficients were computed. The square of $\beta$ coefficient multiplied by 100 indicates the proportion of additional variance explained by each independent variable. $\beta$ coefficients of the multiple regression analysis serve as the parameters of the regression equation (linear trend). The special multiple regression analysis on merged files from different years enabled us to answer the question on the structural change in demographic factors between 1990 and 1997. The FBS data files from different years were weighted to assure the same number of cases in all files, and then compared by using new variables ('dif' variables) connected with the year of the survey.

Henceforth in this article, there is no difference between the terms 'consumption' and 'expenditures'.

\section{Description of the General Changes in Consumption Patterns}

It is a common fact that higher income households have higher levels of total expenditures, but the marginal expenditures with the rise of income (between different quintiles of income distribution) are generally decreasing. Table 2 shows the very specific position of the richest households in the Czech Republic: the trend of a decrease in marginal expenditures is interrupted very significantly between the 4th and the 5 th income quintile groups when the marginal expenditures are much higher than between the 3rd and the 4th quintile groups. The richest households from the viewpoint of consumption behaviour form a very particular class and their standard of living has completely altered towards Western consumerism; membership in new financial oligarchic class is connected with the unlimited consumerism and low level of savings. Consumerism is perhaps considered by the 'new rich' as the most apparent sign of their success, position and welfare. 
Table 2. Average total expenditures according to the income of household

\begin{tabular}{lrc} 
Income quintiles & Average total expenditures & Marginal expenditures \\
\hline 1993 & & \\
first quintile & 3452.18 & \\
second quintile & 6240.02 & 2787.84 \\
third quintile & 8545.13 & $\downarrow 2305.11$ \\
forth quintile & 10010.82 & $\downarrow 1465.69$ \\
fifth quintile & 13609.88 & $\uparrow \mathbf{3 5 9 9 . 0 6}$ \\
1997 & & \\
first quintile & 5930.25 & \\
second quintile & 9865.53 & $\downarrow 3535.28$ \\
third quintile & 13408.46 & $\downarrow 3014.09$ \\
forth quintile & 16422.55 & $\uparrow \mathbf{7 2 9 0 . 2 8}$ \\
fifth quintile & 23712.83 &
\end{tabular}

Source: $\quad$ FBS 1993, 1997.

Note: $\quad$ Income quintiles are computed from the total net income of household. Average total expenditures are the total monthly expenditures of a household. Marginal expenditures are defined as a differentiation between quintile groups in values of average total expenditures.

Table 3. Relative expenditures during the Czech transition

\begin{tabular}{lrrrrrrrr} 
& 1990 & \multicolumn{1}{c}{1991} & 1992 & 1993 & 1994 & 1995 & 1996 & 1997 \\
\hline food & 29.09 & 30.80 & 29.75 & 31.78 & 29.05 & 29.86 & 30.75 & 29.13 \\
beverages + tobacco & 7.68 & 7.36 & 6.97 & 5.72 & 6.74 & 7.09 & \multicolumn{1}{c}{5.8} & 5.65 \\
housing & 10.92 & 11.89 & 14.79 & 17.03 & 17.45 & 17.46 & 17.62 & 19.37 \\
housing equipment & 8.05 & 8.06 & 7.75 & 8.05 & 7.77 & 6.87 & 8.59 & 8.68 \\
transport & 10.5 & 10.33 & 9.77 & 8.92 & 10.01 & 10.67 & 9.48 & 9.1 \\
clothing + footwear & 12.35 & 10.40 & 9.45 & 9.65 & 8.94 & 6.68 & 6.14 & 5.46 \\
personal care & 2.77 & 4.46 & 5.03 & 4.19 & 5.25 & 5.45 & 4.89 & 5.09 \\
leisure time & 11.79 & 10.92 & 11.20 & 11.01 & 10.38 & 11.28 & 13.1 & 13.09 \\
miscellaneous & 6.95 & 5.92 & 5.48 & 4.14 & 4.69 & 4.86 & 4.11 & 4.43 \\
\hline
\end{tabular}

Source: $\quad$ FBS's 1990-1997

Note: $\quad$ Relative expenditures are defined as the share of $\mathrm{x}$-expenditures on the total household expenditures.

Table 3 shows the change in the composition of household expenditures of the average Czech household during the transition from 1990 to 1997 (changes in relative expenditures); Table 4 provides the relevant information on the change in the amount of absolute nominal (in current prices) and absolute real (in 1990 prices) expenditures on selected consumption items for the years 1990, 1993 and 1997. ${ }^{3}$

3) Absolute real expenditures are defined as the total average monthly expenditures of households in 1990 prices (according to the inflation index received from the Czech Statistical Office); absolute nominal expenditures are defined as the total average monthly expenditures of households in current prices (sometimes, when it is mentioned, per head of a household). 
Table 4. Monthly absolute nominal and real expenditures 1990, 1993, 1997 (in CZK)

\begin{tabular}{|c|c|c|c|c|c|c|c|}
\hline & \multicolumn{4}{|c|}{ inflation } & \multicolumn{3}{|c|}{ inflation } \\
\hline & \multicolumn{2}{|c|}{ nominal nominal } & index & \multirow{2}{*}{$\begin{array}{l}\text { real } \\
1993\end{array}$} & \multirow{2}{*}{\multicolumn{2}{|c|}{$\begin{array}{l}\text { nominal index } \\
19971997 / 1990\end{array}$}} & \multirow{2}{*}{$\begin{array}{c}\text { real } \\
1997\end{array}$} \\
\hline & 1990 & 1993 & 1993/1990 & & & & \\
\hline Total & 5033 & 7626 & 210.3 & 3627 & 13203 & 297.9 & 4432 \\
\hline Food. Beverages and Tobacco & 1666 & 2624 & 187.3 & 1401 & 4155 & 256.6 & 1619 \\
\hline $\begin{array}{l}\text { Bread and cereals } \\
\text { (pastries, flour, noodles) }\end{array}$ & 134 & 297 & 230.4 & 129 & 493 & 352.6 & 140 \\
\hline Meat & 400 & 572 & 171.9 & 333 & 884 & 239.0 & 370 \\
\hline Fish & 24 & 22 & 235.0 & 10 & 48 & 301.1 & 16 \\
\hline Milk, milk products, eggs & 187 & 384 & 257.6 & 149 & 601 & 355.3 & 169 \\
\hline Oils and fat & 109 & 172 & 151.3 & 114 & 221 & 188.6 & 117 \\
\hline Fruit & 92 & 150 & 161.2 & 93 & 219 & 217.6 & 101 \\
\hline Vegetables & 50 & 81 & 179.3 & 45 & 161 & 232.6 & 69 \\
\hline Potatoes and potato products & 17 & 39 & 189.6 & 21 & 62 & 261.7 & 24 \\
\hline Sugar and other food & 100 & 212 & 150.5 & 141 & 318 & 203.9 & 156 \\
\hline Non-alcoholic beverages & 47 & 155 & 183.7 & 84 & 331 & 205.8 & 161 \\
\hline Alcoholic beverages & 161 & 212 & 164.8 & 129 & 298 & 199.4 & 150 \\
\hline Tobacco & 69 & 133 & 229.1 & 58 & 202 & 328.8 & 61 \\
\hline Clothing and Footwear & 643 & 802 & 211.5 & 379 & 1063 & 311.3 & 342 \\
\hline Clothing & 504 & 518 & 195.6 & 265 & 799 & 281.4 & 284 \\
\hline Footwear & 117 & 162 & 269.2 & 60 & 264 & 421.6 & 63 \\
\hline Housing & 500 & 1122 & 279.3 & 402 & 2417 & 466.2 & 519 \\
\hline \multicolumn{8}{|l|}{ Furniture, Furnishing and } \\
\hline Household Equipment & 448 & 677 & 224.7 & 301 & 1198 & 279.2 & 429 \\
\hline Furniture and fixtures & 83 & 158 & 200.8 & 79 & 280 & 249.8 & 112 \\
\hline Household textiles & 176 & 68 & 241.6 & 28 & 89 & 297.4 & 30 \\
\hline $\begin{array}{l}\text { Heating and cooking appliances, } \\
\text { refrigerators, washing machines, etc. } \\
\text { Glassware, tableware, glasses }\end{array}$ & 102 & 134 & 197.4 & 68 & 300 & 229.6 & 131 \\
\hline and household utensils & 34 & 65 & 234.3 & 28 & 94 & 312.0 & 30 \\
\hline Garden appliances & - & 13 & 249.7 & 5 & 58 & 333.6 & 17 \\
\hline $\begin{array}{l}\text { Household operation } \\
\text { (cleaning. laundry) }\end{array}$ & 122 & 73 & 251.5 & 29 & 86 & 312.0 & 28 \\
\hline Medical Care and Health & 16 & 76 & 191.7 & 39 & 195 & 275.4 & 71 \\
\hline Transport and Communication & 744 & 930 & 204.2 & 456 & 1784 & 275.2 & 648 \\
\hline Personal transport equipment & 243 & 203 & 194.8 & 104 & 467 & 235.5 & 198 \\
\hline $\begin{array}{l}\text { Operation of personal transport } \\
\text { equipment }\end{array}$ & 275 & 464 & 201.0 & 231 & 847 & 268.6 & 315 \\
\hline Public transport & 79 & 159 & 236.9 & 67 & 250 & 372.7 & 67 \\
\hline Communication (postage, telephone) & 74 & 75 & 178.4 & 42 & 220 & 297.4 & 74 \\
\hline \multicolumn{8}{|l|}{ Recreation, Entertainment, Education } \\
\hline and Cultural Services & 358 & 467 & 203.0 & 230 & 988 & 281.7 & 351 \\
\hline Sport goods and accessories & 139 & 82 & 169.3 & 48 & 167 & 200.4 & 83 \\
\hline $\begin{array}{l}\text { Entertainment, recreational } \\
\text { and cultural services }\end{array}$ & 141 & 238 & 189.1 & 126 & 577 & 260.0 & 222 \\
\hline Books, newspapers and paper goods & 78 & 148 & 279.4 & 53 & 244 & 478.8 & 51 \\
\hline
\end{tabular}


Table 4 (cont.). Monthly absolute nominal and real expenditures 1990, 1993, 1997 (in CZK)

\begin{tabular}{lrrrrrrr} 
& \multicolumn{3}{c}{ inflation } & \multicolumn{3}{c}{ inflation } \\
& \multicolumn{1}{c}{ nominal nominal } & index & real & nominal index & real \\
& 1990 & 1993 & $1993 / 1990$ & 1993 & 1997 & $1997 / 1990$ & 1997 \\
\hline Restaurants and Hotels & 219 & 332 & $\mathbf{2 1 9 . 7}$ & 151 & 580 & $\mathbf{2 9 9 . 9}$ & 193 \\
Restaurants and cafes & 39 & 79 & $\mathbf{2 2 6 . 3}$ & 35 & 205 & $\mathbf{3 0 5 . 6}$ & 67 \\
Firm canteens & 116 & 172 & $\mathbf{1 8 0 . 9}$ & 95 & 248 & $\mathbf{2 4 5 . 8}$ & 101 \\
Hotels and similar lodging services & 5 & 11 & $\mathbf{3 3 1 . 5}$ & 3 & 20 & $\mathbf{5 7 2 . 5}$ & 4 \\
Education & 16 & 42 & $\mathbf{2 0 4 . 3}$ & 21 & 40 & $\mathbf{4 3 9 . 4}$ & 9 \\
Miscellaneous Goods and Services & 333 & 335 & $\mathbf{2 1 0 . 0}$ & 160 & 585 & $\mathbf{2 8 6 . 6}$ & 204 \\
Personal care & 25 & 75 & $\mathbf{2 2 8 . 2}$ & 33 & 140 & $\mathbf{2 9 7 . 6}$ & 47 \\
\hline
\end{tabular}

Source: $\quad$ Family Budgets Surveys 1990, 1993, 1997

Note: $\quad$ Nominal expenditures are defined as the average monthly x-expenditures of the household in current prices. Real expenditures are defined as the average monthly $\mathrm{x}$ expenditures of the household in 1990 prices.

\section{Food}

According to Eurostat [Eurostat... 1998], the share of food consumption out of total consumption in the average EU household was around 14\% in 1993 (with the lowest in the United Kingdom, 10.8\%, and the highest, in Greece, 28.3\%). Every society naturally has its own traditional cultural pattern of consumer behaviour. In Ireland or in the United Kingdom, there are relatively low food expenditures (in stores) in comparison with some other European countries, simply because of the fact that Irish and British households spend much more of their income on meals in restaurants and pubs; for a comparison, Irish households spent $7.27 \%$ of their average budget in restaurants and cafés in 1988 and Danish households, conversely, only $0.22 \%$ of their average budget.

In the Czech Republic, the average relative food expenditures rose from $29.1 \%$ to $31.8 \%$ between 1990 and 1993, then they decreased to the level of $29.4 \%$ in 1994 , and again increased to the level of $30.7 \%$ in 1996. In 1997 the relative food expenditures were $29.1 \%$. In absolute real values, there was a slight decrease in real food, beverage and tobacco expenditures from 1,665 CZK to 1,401 CZK between 1990 and 1993 and, similarly, a slight growth to 1,619 CZK in 1997. According to the results from FBS' analysis, the real food, beverage and tobacco expenditures still did not reach the levels of 1990 in 1997. Price liberalisation led to a growth in the variety of food and to greater choices for the consumer, but for most of the middle and low income households it led to a huge decrease in their purchasing power (see the inflation index in Table 4).

The high value of relative food expenditures (in comparison with the EU standards) is not only the result of wide economic reform, slow economic growth and the new 'food consumerism', but it may also be a result of a lack of any efficient housing reform in the Czech Republic. In the case of the EU countries, there was also a sharp rise of relative housing expenditures which had a great influence on the decrease of relative food expenditures: according to INSEE [Cases 1999], the total absolute real food and beverage expenditures in 1980 prices rose 94\% in France between 1960 and 1997, but the real housing expenditures rose $358 \%$ in the same period. 


\section{Housing}

According to Eurostat the relative housing expenditures of European households rose from $18 \%$ to $19.8 \%$ between 1986 and 1995; the highest growth was apparent in Sweden (seven percentage points), Finland (five percentage points), France and Italy. Figure 1 provides an international comparison of the coefficients of the housing burden, defined as the average shares of total housing expenditures out of the total net income of households; the data for the European countries refer to 1992 [Cecodhas 1995], the data for the Czech Republic refer to 1996, the data for Hungary to 1997, the data for Poland to 1996, and the data for Slovenia to 1994 (in all cases without the market rental sector). The low coefficients of the housing burden in southern European countries are mostly explained by the tradition of living in large families where more economically active members of the household share housing costs. The low quality of housing and relatively lower energy expenditures belong among the other reasons.

The housing sphere demands special attention. In international comparisons, the concept of imputed rent for owner occupied housing is applied. This, however, is not possible in the case of the Czech Republic, due to the wide defects and many dysfunctions of the Czech rental sector which have survived from the period of communism. Moreover, the housing expenditures on primary housing are not separated from the expenditures on secondary housing in FBS's, and the number of families with secondary residences is relatively high in Czech society. ${ }^{4}$

Alongside the problems with secondary housing in the Czech environment, other important aspects of the comparison should be mentioned. First, the coefficients for the EU countries are already reduced by a housing benefit that forms a very important part of their housing policies; conversely it has no meaning in the Czech environment. ${ }^{5}$ Secondly, the coefficient from the Cecodhas source relates to the situation in 1992, and it can be expected that the actual coefficients are higher. According to the Netherland Ministry of Housing, the average coefficient of the net rent burden (the share of net rent out of total net income) was $21.1 \%$ in the Netherlands in 1995; given the assumptions that imputed rent in the ownership sector is generally higher than in the rental sector, and that the rent forms two thirds of total housing expenditures, we can expect that the real coefficient of the housing burden is actually between 6 and 7 percentage points higher than the Figure 1 shows [Ministerie... 1998]. According to the Housing Finance Review 1999/2000 by Steve Wilcox [1999], the average coefficient of the housing burden was $25 \%$ in Great Britain 1998, i.e. 5 percentage points higher than is indicated in the figure. Similarly, the results from the survey Enquête Logement 1996/1997, realised by INSEE, show a difference of three percentage points; the average coefficient of the housing burden was $26.7 \%$ in the rental sector without a housing benefit, and $23 \%$ with a housing benefit, while the average coefficient of the housing burden was $24.1 \%$ in the ownership sector, and $23.1 \%$

4 ) According to the 1991 census of households, $12.7 \%$ of households indicated they have a secondary residence, but according to the 1991 census of housing residencies (including cottages not separated from the list of primary housing, and flats that are not occupied), this share is probably higher (about 15\%). In the EU-12 [Eurostat... 1998] the average share of households with a secondary residence was $9 \%$ in 1994, with the highest percentage in Spain (16\%).

5 ) The share of households receiving housing benefits was 27\% in France, 22\% in Denmark, 18\% in Spain, 20\% in Great Britain, 13\% in Sweden, etc. Conversely, this share was only 3.6\% in the Czech Republic (1998). 
with a housing benefit. According to our estimation the real coefficient of the housing burden (with a housing benefit) was then around 23\% in France in 1997. The gap between the situation in the Czech Republic and in the EU countries is therefore deeper than is shown in Figure 1.

Figure 1. The relative housing expenditures (of total net income) in the EU and CEE countries $(\%)$

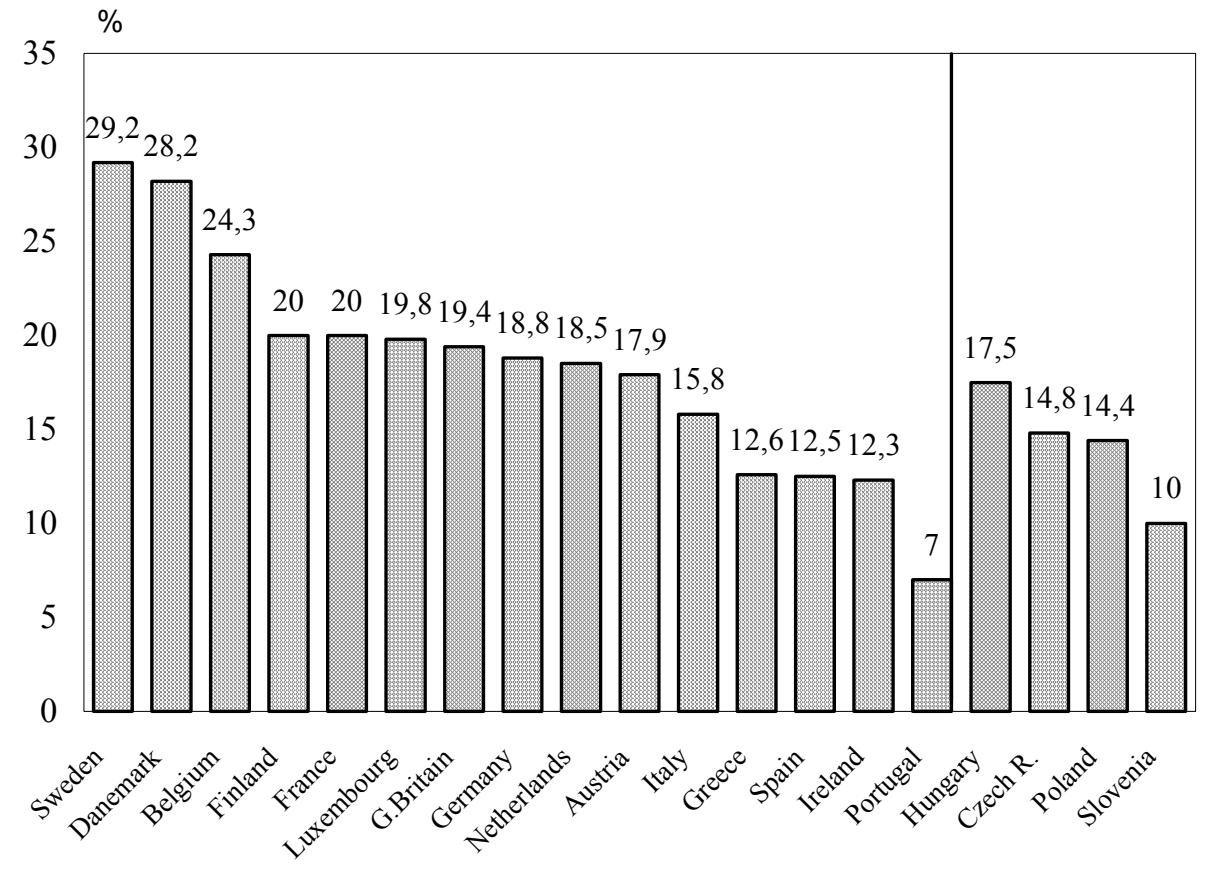

Source: [Cecodhas 1995], FBS 1996, [Regional... 1995, Price... 1998], Urząd Mieskalnictwa i Rozwoju Miast 1999.

Though it is correct to say that housing expenditures rose in their absolute nominal and relative values in the Czech Republic between 1990 and 1997 (relative expenditures from $10.9 \%$ in 1990 to $19.3 \%$ in 1997), due to the above mentioned problems the actual relative housing expenditures were, by our estimation, roughly 2 or 3 percent lower than is indicated in Table 3 (about 16,5\% in 1997). The liberalisation of rents has had a much lower impact on their growth in comparison with the rise in energy prices; expenditures of households on energy (electricity, heating) compose two thirds of the total housing expenditures in the rental sector, while rent forms only one third of total expenditures at present. In 1997, rent formed only 5.5\% of total net household income and only $32.1 \%$ of all housing expenditures in the average Czech household! The opposite is true in European Union countries. In France, for example, the rent formed 19\% of the total net household income and $69.4 \%$ of all housing expenditures of the average French household in the rental sector in 1996 [Enquête... 1997].

Prices of privately owned flats and of family houses have grown geometrically since 1990, and up to 1998 the annual rise in prices of estates was above the general inflation rate. The decrease in new housing construction, along with the rise of prices in hous- 
ing, has led to in a growing number of households in the situation of 'unwanted coexistence' with parents. By estimation, this number rose from 170,000 households in 1991 to 300,000 in 1999 (currently it constitutes 7-7.5\% of all Czech households). Though housing construction has slightly increased since 1993, after a deep decline between 1991 and 1993, the share of rental housing construction out of the total housing construction that had been initiated was only $6.1 \%$ in 1997 . The system of state rent regulation survived not only in the municipal flats but also in 'private' rental flats (houses returned to their former owners), and the regulated rent for the average rental flat was still 6 times lower than the market rent for this kind of flat on average and did not even cover maintenance costs in 1998. According to our computation, higher income households had the highest hidden profit from rent regulation! ${ }^{6}$ As a consequence, there occurred strong social tension between households in 'unwanted coexistence' and households with privileged rent contracts, as well as a tension between households of pensioners and households with an economically active head.

\section{Clothing and Footwear}

According to Table 1, the average value in relative clothing expenditures in the EU countries was 7.1\% in 1993 (with the highest in Portugal and Italy, 9.3\%, and the lowest in Finland, 4.6\%). Between 1990 and 1997, clothing expenditures decreased in their absolute real value from $643 \mathrm{CZK}$ to $311 \mathrm{CZK}$ in the Czech Republic; relative clothing expenditures fell from $12.35 \%$ in 1990 to $5.46 \%$ in 1997 . It is obvious that this sharp decrease in absolute real and relative clothing expenditures is firmly connected with the rise in 'necessary expenditures' (food, housing). For comparison: in France, there was a decrease in relative clothing expenditures from $10.99 \%$ in 1960 to $5.2 \%$ in 1997 ; over a period of 37 years there has never been such a dramatic decrease as there was during the period of 7 years in the Czech Republic. It can be expected then that the share of clothing expenditures will grow as a result of potential economic growth in the future.

The fact of the decrease in 'unnecessary expenditures' is curious, mainly for the character of its 'redistribution': the relative expenditures on personal care, recreation, entertainment, education and cultural services (leisure time activities) increased between 1990 and 1997! Compensation for the growth in 'necessary expenditures' was not equally distributed among all 'unnecessary' items, but there was, on the one hand, a slight decrease in the relative consumption of alcoholic beverages and tobacco, and transport and communication, and a sharp decrease in relative clothing expenditures; on the other hand, there was stagnation or growth in the relative expenditures of the aforementioned consumption items.

One particular interpretation of the relative clothing expenditure decrease seems highly probable: after 1990, many shops and kiosks with cheap Asian clothing sold by the Vietnamese minority were opened. This also includes the appearance of second-hand stores. The clothing at kiosks or in second-hand shops was much cheaper than in most normal clothing stores. The kiosk gained in popularity among lower income households and the second-hand shops were popular throughout the entire population.

${ }^{6}$ ) This fact was tested by a large comparison of regulated and market rents for the same kind of flats when the coefficient of the undervaluation of rent regulated flats was computed. This coefficient was higher for higher income households than for lower income households: the higher income households thus have a higher profit from the regulation. 
Leisure time (recreation, education, entertainment, culture, books, television, sport, restaurants and hotels in specific case)

The average value in relative leisure time expenditures was $8.6 \%$ in 1993 , with the highest in Ireland (11.9\%) and the lowest in Luxembourg (4.1\%) and Greece (5.3\%); the restaurant expenditures are included. The sphere of leisure time and recreation is completely open to national differentiation. The high share of restaurant expenditures in Ireland and Great Britain was already mentioned, and some differences are also apparent in the sphere of recreation: in 1998 Dutch households spent 1.75\% of their budget on hotels and lodging services, Luxembourg households only $0.04 \%$ of their budget.

The expenditures in restaurants and cafes are included in 'leisure time' relative expenditures for the Czech Republic in Table 3 and are excluded in Table 4 (there is a separate item concerning public alimentation). In both cases, we can see a growth (!) in the relative leisure time expenditures (in Table 3 from $11.8 \%$ in 1990 to 13.1\% in 1997); this increase was very sharp between 1995 and 1996 and it was connected mainly with higher recreation expenditures and partially with higher sport and restaurant expenditures. ${ }^{7}$ The growth in expenditures for recreational services and services rendered by restaurants is apparent even in the case of absolute real expenditures (Table 4).

The sphere of leisure time expenditures is precisely the sphere in which the main social and income inequalities demonstrate themselves: between 1990 and 1997, real leisure time expenditures increased only for the households from the fourth and the fifth quintile of income distribution (and the highest rise was apparent for the fifth quintile), while the lower income households spent less on leisure time activities in real values in 1997 than in 1990; real leisure time expenditures rose for households in which the head had secondary- or university-level education (and mostly for households in which the head had university-level education), while for households in which the head had elementary-level education, the expenditures have decreased in real values. There are, of course, many other demographic factors influencing this development which the next sections should explain.

\section{Other}

Transport expenditures form $14.8 \%$ of the European households' budgets. In the Czech Republic the real and relative expenditures on transport and communication slightly decreased (from $10.5 \%$ in 1990 to $9.1 \%$ in 1997 in relative values). Though there was a decrease in the real expenses of buying the vehicles, the real expenses of operating the vehicles was higher in 1997 than in 1990. This would lead to the conclusion that there were fewer cars (or fewer car sales) in 1997 than in 1990. Such a conclusion does not correspond to reality, however, for car sales increased dramatically after 1990, so that there are now many more cars on Czech roads than ever before. The explanation lies in the fact that most new car purchases were made by businesses, and households also used these business vehicles privately. The real expenditures on public transport were a little bit less in 1997 than they were in 1990.

\footnotetext{
7) The higher restaurant expenditures are partly connected with the decrease in the possibility of 'canteen alimentation' since 1990; mostly white-collar workers were then forced to have lunch in restaurants.
} 
The real expenditures on furniture, furnishings and household equipment and operation were on the increase after 1993, but they had not reached the level of 1990 by the end of 1997. Conversely, there was a permanent rise in real medical care and health expenses: in 1997, real expenses were 4.4 times higher in real values than in 1990. After the reform of the health service (introduction of health insurance) not all health costs (prescriptions, medical investigation) are fully covered by insurance agencies, and households must contribute to health expenditures out of their own budgets.

\section{Factors behind the Change in Consumer Behaviour}

The next comparison and analysis concentrates on four consumer items: food, clothing, housing and leisure time activities. Their change is described using the 1990, 1993 and 1997 data files.

\section{Income}

Income means the total net income of a household (net after taxes, health and social insurance). The relative food and housing expenditures decrease with the level of income, and the relative clothing and leisure time expenditure rise with the level of income in all three years. The average nominal monthly food expenditures per capita took the highest values for households from the first quintile of income distribution (poorest households) for all three years, but the income factor must be very carefully interpreted. There is a very significant spurious correlation between the total net income and the number of household members, which means that the higher the number of members the higher the total net income a household has. This fact reflects a large income gap between families with economically active members (mostly with children) and those with economically non-active members (children do not live with parents anymore). The expenditures in restaurants are not included into food expenditures; the higher income households were more often boarding out of their homes. ${ }^{8}$

Similarly, poor households spent a much higher nominal amount per capita on their housing than higher income households (with the exception of households from the fifth quintile of income distribution in 1997). In 1997, the households from the first quintile group had relative housing expenditures about 10 percentage points higher than the households from the fifth quintile. The significant negative correlation between housing expenditures in their absolute values per capita and the total net income disappeared again when it was tested for the influence of the family's size. According to our expectations, clothing and leisure time expenditures in their absolute nominal values rise with the level of the total net income of a household (for all three years). The rise in structural income and expenditure inequalities demonstrates itself mostly in the sphere of leisure time activities: in 1990, the households from the fifth quintile spent $65 \%$ more on leisure time activities than the households from the first quintile, in 1993 93\%, and in $1997111 \%$ more.

8) The households from the last income quintile spent about 29\% more on leisure time activities (restaurants included) than the households from the first quintile in 1990, and about 55\% more in 1997. While there is a differential between the first and last quintile of $100 \mathrm{CZK}$, both in the case of food expenditures and leisure time activities in 1990, this differential in the case of food expenditures rises to $200 \mathrm{CZK}$ and in the case of leisure time activities to $600 \mathrm{CZK}$ in 1997. 
Age

Age indicates the age of the head of a household. There are no apparent changes in the structure of consumption patterns according to the age categories between 1990 and 1997 (Table 5). For all three years:

- Relative food expenditures were increasing with age;

- Relative clothing expenditures were decreasing at the beginning, rising for households with a household head aged from 35 to 44 years, and then sharply decreasing (in 1997 they were decreasing from the age category $45-49$ years);

- Relative housing expenditures were decreasing at the beginning, and the category of households aged 40-44 was the turning point after which relative housing expenditures were further rising with age;

- Relative leisure time expenditures were rising up to the age of 35-39 in 1990, and the age of 40-44 years in 1993 and 1997, and then decreasing with age.

Table 5. Relative expenditures according to the age of the head of the household 1990, 1993, 1997

$\begin{array}{llllllllll}18-29 & 30-34 & 35-39 & 40-44 & 45-49 & 50-54 & 55-59 & 60-64 & 65-69 & 70-74 \\ \text { total }\end{array}$

1990

food

housing

clothing

leisure time

1993

food

housing

clothing

leisure time

1997

food

housing

clothing

leisure time

Source:

Note:

\begin{tabular}{rrrrrrrrrrr}
22.74 & 24.26 & 26.16 & 26.88 & 27.24 & 27.32 & 28.31 & 31.94 & 38.76 & 38.19 & 29.09 \\
11.65 & 10.56 & 9.10 & 8.86 & 9.81 & 9.86 & 10.37 & 11.98 & 13.18 & 14.91 & 10.92 \\
14.22 & 13.51 & 13.80 & 14.59 & 13.35 & 13.05 & 12.45 & 10.09 & 8.73 & 8.56 & 12.35 \\
13.04 & 13.67 & 13.95 & 13.61 & 12.80 & 12.07 & 11.75 & 10.44 & 8.25 & 6.61 & 11.79 \\
& & & & & & & & & & \\
26.42 & 26.17 & 28.14 & 29.13 & 28.29 & 29.43 & 31.30 & 36.67 & 39.72 & 41.24 & 31.78 \\
16.64 & 15.37 & 13.39 & 13.07 & 13.59 & 15.37 & 17.31 & 22.03 & 21.04 & 23.28 & 17.03 \\
11.61 & 10.90 & 11.28 & 11.98 & 11.30 & 10.68 & 9.24 & 6.81 & 6.44 & 5.76 & 9.65 \\
11.13 & 11.68 & 12.49 & 13.37 & 12.09 & 11.54 & 10.55 & 8.49 & 8.80 & 9.07 & 11.01 \\
& & & & & & & & & & \\
24.91 & 26.47 & 26.33 & 27.05 & 26.01 & 26.31 & 28.88 & 31.69 & 35.41 & 37.22 & 29.13 \\
18.33 & 17.28 & 16.18 & 16.76 & 17.15 & 17.68 & 18.58 & 22.64 & 24.58 & 23.58 & 19.37 \\
6.69 & 6.18 & 6.15 & 6.43 & 6.86 & 5.89 & 5.44 & 4.10 & 3.57 & 3.62 & 5.46 \\
14.30 & 15.33 & 15.55 & 15.89 & 14.24 & 13.03 & 11.34 & 10.76 & 9.79 & 10.02 & 13.09 \\
\hline
\end{tabular}

Family Budget Surveys 1990, 1993, 1997

Relative expenditures are defined as the share of $\mathrm{x}$-expenditures out of total household expenditures.

In comparison with the situation in Germany [Borsch-Supan 1994: 231] there are some specific features in this consumer structure. In the sphere of food expenditures there is no great inequality between 'younger' and 'older' households: there was a differential of 2.4 percentage points between the youngest (21-24 years) and the oldest (70-74) in relative food expenditures in Germany in 1983 (in CR 199712.3 percentage points!), a differential of 3.6 percentage points in relative leisure time expenditures (in CR 4.3 percentage points) and a differentiation of 0.1 percentage points in relative clothing expenditures (in CR 3.1 percentage points). The correlation between relative clothing expenditures in Germany (relative expenditures increase with age up to the age category 70-74 years) is precisely opposite to the correlation in the Czech environment (relative expenditures are 
already decreasing from the age of 45-49 years). The very low standard of living among older Czech households is a consequence of communist limits on the accumulation of assets. Conversely, in France, $33 \%$ of all private wealth is concentrated in the hands of people over 60 , and $50 \%$ of all private wealth is in the hands of people over 50 [Tréquer 1998]; in 1994, people over 50 received $43 \%$ of the total net income of all French households!

\section{Other}

Table 6 provides the relative expenditures of households according to the number of children. While relative food and clothing expenditures rose for households with two or more than two children, absolute nominal food expenditures per capita decreased with the number of children. This situation is equalised in the sphere of housing where fixed costs of housing escalate the relative and absolute values of housing expenditures for those households without children. This differential is strengthened over time: households without children paid in absolute value about $87 \%$ more than households with more than 2 children in 1990, and about 132\% more in 1997. There is a big leap between households without children and households with one child in relative leisure time expenditures.

Table 6. Relative expenditures according to the number of children of a household 1990, 1993, 1997

\begin{tabular}{|c|c|c|c|c|c|}
\hline & without children & one child & two children & $\begin{array}{l}\text { more than } \\
\text { two children }\end{array}$ & total \\
\hline \multicolumn{6}{|l|}{1990} \\
\hline food & 32.14 & 26.43 & 25.78 & 28.32 & 29.09 \\
\hline housing & 12.23 & 9.86 & 9.35 & 9.21 & 10.92 \\
\hline clothing & 11.25 & 14.38 & 14.15 & 14.25 & 12.35 \\
\hline leisure time & 10.82 & 13.14 & 13.25 & 12.26 & 11.79 \\
\hline \multicolumn{6}{|l|}{1993} \\
\hline food & 34.12 & 27.79 & 28.26 & 31.69 & 31.78 \\
\hline housing & 20.24 & 15.32 & 13.72 & 11.36 & 17.03 \\
\hline clothing & 8.21 & 10.86 & 11.68 & 11.58 & 9.65 \\
\hline leisure time & 10.27 & 11.86 & 12.15 & 11.75 & 11.01 \\
\hline \multicolumn{6}{|l|}{1997} \\
\hline food & 31.28 & 24.65 & 27.83 & 29.59 & 29.13 \\
\hline housing & 22.31 & 17.27 & 16.24 & 14.57 & 19.37 \\
\hline clothing & 5.28 & 6.35 & 6.42 & 5.89 & 5.46 \\
\hline leisure time & 12.28 & 14.63 & 14.87 & 15.23 & 13.09 \\
\hline
\end{tabular}

Source: $\quad$ Family Budgets Surveys 1990, 1993, 1997

Note: $\quad$ Relative expenditures are defined as the share of $\mathrm{x}$-expenditures out of total household expenditures.

Table 7 shows the consumer differences between households with economically active (EA) heads and households of pensioners. Households with EA heads spent significantly more on clothing and leisure time activities in both relative and absolute values, households of pensioners were forced to have much higher relative and absolute nominal food and housing expenditures per head. All the means are - statistically significantly - different on the level of reliability 0.05 (t-test). 
Table 7. Relative expenditures according to the economic activity of the head of a household 1990, 1993, 1997

\begin{tabular}{lrrr} 
& EN head & EA head & total \\
\hline 1990 & & & \\
food & 39.29 & 26.35 & 29.09 \\
housing & 14.32 & 9.63 & 10.92 \\
clothing & 7.75 & 14.28 & 12.35 \\
leisure time & 6.76 & 13.15 & 11.79 \\
1993 & & & \\
food & 40.22 & 27.91 & 31.78 \\
housing & 23.26 & 14.66 & 17.03 \\
clothing & 6.13 & 10.61 & 9.65 \\
leisure time & 8.89 & 12.15 & 11.01 \\
l997 & & & \\
food & 36.25 & 25.58 & 29.13 \\
housing & 25.27 & 16.84 & 19.37 \\
clothing & 3.47 & 6.15 & 5.46 \\
leisure time & 9.75 & 14.41 & 13.09 \\
\hline Source: & & &
\end{tabular}

Source: $\quad$ Family Budgets Surveys 1990, 1993, 1997

Note: $\quad$ Relative expenditures are defined as the share of $\mathrm{x}$-expenditures out of total household expenditures.

The factor of education is also a very important sociological constant in explaining different consumer behaviour. Education is defined as the highest level of education of the head of the household. The elementary education of the head of the household is connected with higher relative and absolute food and housing expenditures and, conversely, the university education of the head of the household is connected with higher relative and absolute clothing and leisure time expenditures (Table 8). These inequalities were strengthened between 1990 and 1997, mostly in the case of leisure time expenditures: in absolute values, households in which the head had university education had about $95 \%$ higher leisure time expenditures in 1990 than households in which the head had elementary education, and about $135 \%$ higher in 1997. The higher the level of acquired education is, the higher the relative expenditures on books, computers, sport, lodging, education, culture and recreation are; this relation does not apply in the case of expenditures in restaurants and cafés. Scheffé's and Duncan's testing confirm the significance of differences between means for all values of relative expenditures with the exception of housing expenditures, where only the average value for households with an elementary educated head was significantly different from all other mean values. 
Table 8. Relative expenditures according to the level of completed education of the head of the household 1990, 1993, 1997

\begin{tabular}{|c|c|c|c|c|c|}
\hline $\begin{array}{l}\text { Education } \\
\text { of head }\end{array}$ & elementary & $\begin{array}{c}\text { vocational } \\
\text { training }\end{array}$ & secondary & university & total \\
\hline \multicolumn{6}{|l|}{1990} \\
\hline food & 37.26 & 29.58 & 26.75 & 24.21 & 29.09 \\
\hline housing & 13.21 & 9.58 & 10.23 & 10.42 & 10.92 \\
\hline clothing & 9.85 & 12.24 & 12.84 & 12.41 & 12.35 \\
\hline leisure time & 8.02 & 11.21 & 12.57 & 12.32 & 11.79 \\
\hline \multicolumn{6}{|l|}{1993} \\
\hline food & 40.02 & 31.82 & 29.74 & 26.28 & 31.78 \\
\hline housing & 21.32 & 17.13 & 17.28 & 14.69 & 17.03 \\
\hline clothing & 7.39 & 9.15 & 9.86 & 11.12 & 9.65 \\
\hline leisure time & 7.65 & 10.27 & 11.82 & 12.85 & 11.01 \\
\hline \multicolumn{6}{|l|}{1997} \\
\hline food & 35.68 & 30.57 & 27.42 & 24.20 & 29.13 \\
\hline housing & 23.18 & 18.87 & 20.08 & 19.43 & 19.37 \\
\hline clothing & 3.85 & 5.28 & 5.87 & 5.78 & 5.46 \\
\hline leisure time & 9.68 & 12.08 & 13.85 & 17.08 & 13.09 \\
\hline
\end{tabular}

Source: $\quad$ Family Budgets Surveys 1990, 1993, 1997

Note: $\quad$ Relative expenditures are defined as the share of $x$-expenditures out of total household expenditures.

There are some differences between the Czech regions ${ }^{9}$ in relative expenditure structure, and there is a slight sign of change towards greater differentiation between 1990 and 1997. Scheffé's testing of means did not find any significant difference in relative housing, clothing or food expenditures between regions; the leisure time expenditures formed the only exception because Prague households paid significantly more on leisure time activities than the rest of the Republic (the lowest relative and absolute leisure time expenditures seem to be in Moravian regions). In 1997, Praguers spent in absolute nominal values (per capita) about 13\% more on food that the average Czech household, about 19\% more on housing, about $11 \%$ more on clothing and, the most important feature, about $43 \%$ more on leisure time activities. The Duncan test, which is much less conservative in means testing, confirms the significant difference between Prague and the rest of the Republic, not only in the sphere of leisure time expenditures, but also in the sphere of food, housing and clothing relative expenditures in $1997 .{ }^{10}$ The exceptional position of Prague increased (according to the Duncan tests) between 1990 and 1997.

\section{Multidimensional Analysis of the Factors}

To explain the variation of relative expenditures, the regression and the ANOVA analysis were used. Table 9 provides the standardised $\beta$ coefficients of multiple regression models

9) There are eight main regions in the Czech Republic to date; reform of regional organisation is currently being implemented.

10) The leading position of Prague in all kinds of leisure time expenditures has only one exception: expenditures in restaurants. The region of Pilsen has the highest relative and absolute value of average expenditures in the Czech Republic for all three years. 
(continues variable factors); Table 10 provides the $\beta$ coefficients ${ }^{11}$ of multiple classification analysis forming a part of ANOVA analysis (categorised factors). Both regression and ANOVA confirmed that in all three analysed years:

1. The most influential factors of the variability of relative food expenditures were age (positive correlation) and income (negative correlation), and a less influential factor was the size of residence (change of mark to negative correlation).

2. The most influential factor of the variability of relative clothing expenditures was age (negative correlation), and a less influential factor was the size of residence (change of mark to negative correlation).

Table 9. Multiple regression analysis of relative expenditures 1990, 1993, 1997

\begin{tabular}{|c|c|c|c|}
\hline \multirow[b]{2}{*}{ Variable } & \multicolumn{3}{|c|}{$\beta$ coefficients } \\
\hline & 1990 & 1993 & 1997 \\
\hline \multicolumn{4}{|l|}{ Food } \\
\hline Age of the head & 0.483 & 0.476 & 0.404 \\
\hline Number of children & 0.292 & 0.262 & 0.296 \\
\hline Education of the head & -0.147 & -0.120 & -0.161 \\
\hline Household income & -0.369 & -0.344 & -0.376 \\
\hline Size of residence & $0.014^{*}$ & -0.030 & -0.037 \\
\hline $\mathrm{R}^{2}$ & 0.409 & 0.393 & 0.338 \\
\hline \multicolumn{4}{|l|}{ Clothing } \\
\hline Age of the head & -0.276 & -0.277 & -0.280 \\
\hline Number of children & 0.043 & 0.043 & -0.064 \\
\hline Education of the head & 0.049 & 0.040 & 0.107 \\
\hline Household income & 0.062 & 0.168 & 0.166 \\
\hline Size of residence & $0.021^{*}$ & $-0.030^{*}$ & $-0.030^{*}$ \\
\hline $\mathrm{R}^{2}$ & 0.124 & 0.184 & 0.140 \\
\hline \multicolumn{4}{|l|}{ Housing } \\
\hline Age of the head & 0.066 & 0.097 & 0.143 \\
\hline Number of children & $0.007^{*}$ & -0.039 & -0.042 \\
\hline Education of the head & $0.016^{*}$ & $0.026^{*}$ & $0.023^{*}$ \\
\hline Household income & -0.288 & -0.441 & -0.235 \\
\hline Size of residence & 0.061 & 0.170 & 0.170 \\
\hline $\mathrm{R}^{2}$ & 0.105 & 0.290 & 0.149 \\
\hline \multicolumn{4}{|l|}{ Leisure time } \\
\hline Age of the head & -0.220 & -0.067 & -0.178 \\
\hline Number of children & -0.087 & $-0.014^{*}$ & $0.017^{\star}$ \\
\hline Education of the head & 0.130 & 0.065 & 0.144 \\
\hline Household income & 0.148 & 0.180 & 0.162 \\
\hline Size of residence & 0.068 & 0.065 & 0.178 \\
\hline $\mathrm{R}^{2}$ & 0.115 & 0.084 & 0.129 \\
\hline
\end{tabular}

Source: $\quad$ Family Budget Surveys 1990, 1993, 1997.

Note: $\quad$ All coefficient except ${ }^{*}$ are significant on the level $\alpha<0.005$.

11) Square of the $\beta$ coefficients of ANOVA analysis multiplied by 100 gives the percentage of the explained variability of the dependent variable by the independent variable. 
3. The most influential factor of the variability of relative housing expenditures was income (negative correlation), and less influential factors were education (positive correlation) and the number of children (change of mark to negative correlation).

4. The most influential factors of the variability of relative leisure time expenditures were age (negative correlation) and income (positive correlation), and a less influential factor was the number of children (change of mark to positive correlation).

Both the regression and ANOVA analysis confirmed the importance of age and income, the medium position of education, and the relatively less important position of family size and residence size for the explanation of consumer behaviour in the Czech environment.

Table 10. ANOVA analysis of relative expenditures 1990, 1993, 1997

\begin{tabular}{|c|c|c|c|c|}
\hline Variables & $\begin{array}{l}\text { Number of } \\
\text { categories }\end{array}$ & 1990 & $\begin{array}{c}\text { coefficie } \\
1993 \\
\end{array}$ & 1997 \\
\hline \multicolumn{5}{|l|}{ Food } \\
\hline Age of the head & (4) & 0.446 & 0.443 & 0.416 \\
\hline Number of children & (4) & 0.326 & 0.290 & 0.350 \\
\hline Education of the head & (4) & 0.164 & 0.146 & 0.177 \\
\hline Household income & (5) & 0.418 & 0.357 & 0.367 \\
\hline Size of residence & (5) & $0.023^{*}$ & 0.049 & $0.039^{*}$ \\
\hline $\mathrm{R}^{2}$ & & 0.375 & 0.369 & 0.323 \\
\hline \multicolumn{5}{|l|}{ Clothing } \\
\hline Age of the head & (4) & 0.259 & 0.267 & 0.267 \\
\hline Number of children & (4) & $0.041^{*}$ & $0.053^{*}$ & 0.086 \\
\hline Education of the head & (4) & 0.051 & 0.050 & 0.119 \\
\hline Household income & (5) & 0.091 & 0.169 & 0.146 \\
\hline Size of residence & (5) & 0.058 & 0.062 & 0.078 \\
\hline $\mathrm{R}^{2}$ & & 0.130 & 0.193 & 0.159 \\
\hline \multicolumn{5}{|l|}{ Housing } \\
\hline Age of the head & (4) & 0.059 & 0.087 & 0.129 \\
\hline Number of children & (4) & $0.045^{*}$ & $0.036^{*}$ & $0.007^{*}$ \\
\hline Education of the head & (4) & $0.034^{*}$ & $0.029^{*}$ & $0.020^{*}$ \\
\hline Household income & (5) & 0.370 & 0.467 & 0.294 \\
\hline Size of residence & (5) & 0.089 & 0.184 & 0.169 \\
\hline $\mathrm{R}^{2}$ & & 0.151 & 0.331 & 0.182 \\
\hline \multicolumn{5}{|l|}{ Leisure time } \\
\hline Age of the head & (4) & 0.218 & 0.173 & 0.228 \\
\hline Number of children & (4) & 0.140 & 0.077 & $0.040^{*}$ \\
\hline Education of the head & (4) & 0.138 & 0.137 & 0.143 \\
\hline Household income & (5) & 0.187 & 0.179 & 0.189 \\
\hline Size of residence & (5) & 0.072 & 0.078 & 0.083 \\
\hline $\mathrm{R}^{2}$ & & 0.118 & 0.104 & 0.142 \\
\hline
\end{tabular}

Source: $\quad$ Family Budget Surveys 1990, 1993, 1997

Note: $\quad$ All coefficients except ${ }^{*}$ are significant on the level $\alpha<0.005$.

The regression analysis on merged files 1990-1993, 1993-1997 and 1990-1997 enabled us to describe precisely the main changes in the mutual structure of factors (Table 11). The variables with the prefix 'dif' show the differences (and the significance of these differences) in $\beta$ coefficient values of independent variables between two analysed years (files 
were weighted to obtain the same number of cases). This kind of analysis serves as a confirmation of the ANOVA results.

Table 11. The regression analysis of relative expenditures on merged files 19901993, 1993-1997 and 1990-1997

\begin{tabular}{|c|c|c|c|c|}
\hline \multirow{2}{*}{ Variables } & \multicolumn{4}{|c|}{$\beta$ coefficients } \\
\hline & Food & Clothing & Housing & ure time \\
\hline \multicolumn{5}{|l|}{$1990-1993$} \\
\hline Year & 0.207 & -0.287 & 0.409 & -0.306 \\
\hline Total household income ${ }^{1}$ & -0.375 & 0.104 & -0.294 & 0.193 \\
\hline Age of the head & 0.474 & -0.277 & 0.038 & -0.230 \\
\hline Education of the head & -0.140 & 0.044 & $0.022^{*}$ & 0.132 \\
\hline Size of residence & $0.015^{*}$ & $0.023^{*}$ & 0.050 & 0.075 \\
\hline Number of children & 0.301 & $0.025^{*}$ & 0.040 & -0.112 \\
\hline DIFEDUC & $0.020^{*}$ & $-0.012^{*}$ & $0.014^{*}$ & $-0.015^{*}$ \\
\hline DIFAGE & $-0.045^{*}$ & $0.078^{*}$ & $0.028^{*}$ & 0.311 \\
\hline DIFRES & -0.074 & -0.074 & 0.180 & $0.023^{*}$ \\
\hline DIFCHILD & $-0.017^{*}$ & $0.000^{*}$ & -0.040 & 0.074 \\
\hline DIFINC & $0.015^{*}$ & $0.096^{*}$ & -0.270 & $-0.026^{*}$ \\
\hline $\mathrm{R}^{2}$ & 0.411 & 0.199 & 0.340 & 0.107 \\
\hline \multicolumn{5}{|l|}{ 1993-1997 } \\
\hline Year & $0.042^{*}$ & -0.487 & -0.152 & 0.261 \\
\hline Total household income ${ }^{1}$ & -0.369 & 0.220 & -0.464 & 0.172 \\
\hline Age of the head & 0.454 & -0.271 & 0.047 & -0.051 \\
\hline Education of the head & -0.120 & 0.038 & $0.030^{*}$ & 0.116 \\
\hline Size of residence & -0.035 & $-0.031^{*}$ & 0.154 & 0.064 \\
\hline Number of children & 0.276 & 0.029 & $-0.010^{*}$ & $-0.018^{*}$ \\
\hline DIFEDUC & -0.050 & $0.045^{*}$ & $0.002^{*}$ & $0.046^{*}$ \\
\hline DIFAGE & -0.142 & 0.142 & 0.129 & -0.222 \\
\hline DIFRES & $-0.003^{*}$ & $0.013^{*}$ & $0.036^{*}$ & $0.028^{*}$ \\
\hline DIFCHILD & $0.034^{*}$ & -0.074 & $0.006^{*}$ & $0.017^{*}$ \\
\hline DIFINC & $0.020^{*}$ & -0.085 & 0.161 & $0.011^{*}$ \\
\hline $\mathrm{R}^{2}$ & 0.377 & 0.318 & 0.243 & 0.126 \\
\hline \multicolumn{5}{|l|}{ 1990-1997 } \\
\hline Year & 0.256 & -0.689 & 0.207 & $-0.044^{*}$ \\
\hline Total household income ${ }^{1}$ & -0.387 & 0.101 & -0.257 & 0.181 \\
\hline Age of the head & 0.485 & -0.268 & $0.033^{*}$ & -0.215 \\
\hline Education of the head & -0.143 & 0.042 & $0.019^{*}$ & 0.123 \\
\hline Size of residence & $0.016^{*}$ & $0.023^{*}$ & 0.045 & 0.072 \\
\hline Number of children & 0.308 & $0.024^{*}$ & $-0.035^{*}$ & -0.104 \\
\hline DIFEDUC & $-0.029^{*}$ & $0.025^{*}$ & $0.011^{*}$ & $0.029^{*}$ \\
\hline DIFAGE & -0.190 & 0.193 & 0.153 & $0.084^{*}$ \\
\hline DIFRES & -0.080 & $-0.060^{*}$ & 0.193 & $0.004^{*}$ \\
\hline DIFCHILD & $0.017^{*}$ & -0.061 & $-0.029^{*}$ & 0.085 \\
\hline DIFINC & $-0.005^{*}$ & $0.024^{*}$ & -0.076 & $-0.014^{*}$ \\
\hline $\mathrm{R}^{2}$ & 0.375 & 0.409 & 0.326 & 0.131 \\
\hline
\end{tabular}

Source: $\quad$ Family Budget Surveys 1990, 1993, 1997

Note: $\quad$ All coefficients except ${ }^{*}$ are significant on the level $\alpha<0.005$.

1) Total household income was transformed into 20 categories variable to avoid the influence of inflation. 
DIFEDUC $=$ year $x$ education of the head; year $=1$ or 0

DIFAGE $=$ year $x$ age of the head

DIFRES $=$ year $x$ size of residence

DIFCHILD $=$ year $\mathrm{x}$ number of children

DIFINC $=$ year $\mathrm{x}$ total household income

1. Between 1990 and 1997, the factor of age significantly weakened in importance (positive correlation) and the factor of residence size strengthened in importance as an explanation of the variation of relative food expenditures. In the case of residence size, there appeared even a complete turn of the sign of $\beta$ coefficient of the regression equation, that is, from a positive relation to a negative one: in 1990, the greater the residence size, the higher the relative food expenditures a household had; in 1997, the relation was significantly reversed. This trend seems to reflect the change in food consumption and alimentation norms in towns and in consumption in kind in villages, as well as the growing gap between the standard of living in towns and the standard of living in villages. The factors of the number of children and education slightly weakened in importance between 1990 and 1993 (the number of children in its positive correlation, and education in its negative correlation), but they slightly strengthened their influence between 1993 and 1997; the reverse was the case for the factor of income.

2. A similar change of mark in $\beta$ coefficient appeared in the case of the family size factor and the residence size factor in the explanation of clothing relative expenditures: from 1993 the higher the number of children and the greater the residence size, the lower the relative clothing expenditures a household had (in 1990 the relation was reversed). This change is, however, not statistically significant for the factor of residence size, but it is significant for the factor of the number of children, which strengthened in importance between 1990 and 1997. The households without children are mostly composed of one or two fully employed members and their higher income (per capita) gives them the possibility to spend more on clothing; first-rate clothing may also be a necessity for their employment. Conversely, the factor of age weakened in its significance, especially between 1990 and 1993. Though the factor of income strengthened its importance between 1990 and 1993 significantly, between 1993 and 1997 its influence slightly decreased, and the strengthening of its importance between 1990 and 1997 is not statistically significant.

3. Between 1990 and 1997, the most fundamental changes concerned the variation of relative housing expenditures; four 'dif' variables were significant on the level of 0.95 probability. The factors of age and residence size significantly strengthened their positive influence and the factor of family size strengthened its influence from a positive relation into a negative one (!). These are the consequences of the deregulation of rents and the lack of a good system of housing benefits. The rents were deregulated differently by the government edicts, according to the size of residence, and the growth in rents was therefore higher in larger cities than in smaller ones. The housing benefit did not compensate the growing burden for the lower income households, mostly formed by older households. On the contrary, in the Czech environment a new trend appeared: the higher the number of children a household has the lower the relative housing expenditures are. This is naturally the result of growing higher fixed costs for households without children, but it is also an argument showing that the system of social assistance very firmly supports households with children, and that these households should not gener- 
ally form the potential target group of the new model of housing benefits. The factor of income strengthened its influence between 1990 and 1993, but this importance has weakened significantly between 1993 and 1997. The relative housing expenditures rose for higher income households more than for lower income households in that term, mostly in the ownership-housing sector. There appeared, therefore, no significant change between 1990 and 1997. The factor of education remained completely nonsignificant for all three years.

4. The relatively smallest changes in the factor's structure appeared in the case of relative leisure time expenditures: between 1990 and 1997, the relation between the number of children (a factor itself non-significant in explaining the variability of leisure time expenditures) and relative expenditures has changed from a positive into a negative one; children were the subjects of higher leisure time expenditures than ever before. Though there was a very significant decrease in the importance of the factor of age in its negative relation to relative expenditures between 1990 and 1993, this decrease was followed by a very significant rise in its importance between 1993 and 1997, when new possibilities of leisure time activities for young people appeared (travel, sport).

\section{Conclusion}

The general changes in household consumption during this relatively short historical term took very specific features that are not simply comparable with the consumption trends in the EU countries. Though the relative food expenditures slightly decreased, they remained on the relatively very high level of more than $28 \%$. Though the relative clothing expenditures decreased (and very sharply), this fact seems to be more a compensation for the growing financial burden in the sphere of housing, food and transport than the result of structural historical change. Though housing expenditures increased (and also very sharply) they are still on a relatively low level in comparison with the situation in the EU countries, and this increase was not connected with the structural change in the housing market. The housing rental sector remained in a more or less catastrophic condition, and the growing housing costs in connection with the deregulation of rents were equally distributed among all income groups of households (lack of a housing benefit system): a higher financial burden for lower income households on the one hand, and an accumulation of profits for higher income households on the other are natural consequences. Relative expenditures on transport even slightly decreased, but this was partially caused by new ways of buying and using vehicles, and it may be expected that in the very near future the situation will be reversed.

The rise in nominal 'necessary' expenditures was compensated for mostly by the decrease of expenditures in the sphere of clothing and transport; not in the sphere of leisure time activities. Signs of consumerism among the highest income households appeared. There has been an apparent trend of an escalation in social inequalities between 1990 and 1997, especially in the sphere of leisure time expenditures. The standard of living among 'older' households (pensioners) remains very low.

We cannot confirm the hypothesis that 'meritocratic' factors (income, education) have strengthened and 'demographic' factors (family size, age or residence size) have weakened their influence on explaining the variability of four basic consumer items. The results from multiple regression analysis on merged data files demonstrate that, in the sphere of relative housing expenditures, there is an apparent trend towards the strengthen- 
ing of demographic factors (age, family size, residence size); education is not even significant for explaining variability in housing expenditures. In the sphere of relative food expenditures, the significance of the factor of age grew, but the significance of the factor of residence size decreased; the influence of 'meritocratic' factors remained the same. In the sphere of relative clothing expenditures, the factor of age weakened its influence but the factor of family size has strengthened its influence; similarly, the influence of 'meritocratic' factors did not change. There was also no change in the significance of 'meritocratic' factors in the case of relative leisure time expenditures, and the factor of family size only slightly weakened in importance. Some of the changes had a special transitional character. For example, the factor of age in explaining the variation of relative leisure time expenditures significantly strengthened its importance between 1990 and 1993, but it significantly weakened in importance between 1993 and 1997. The same applies to the factor of income in the case of relative housing expenditures.

MARTIN LUX is a young research fellow working in the department of economic sociology of the Institute of Sociology, Academy of Sciences of the Czech Republic. His main research activities concentrate, on the sphere of housing research, and on research of consumption behaviour changes.

\section{References}

Borsch-Supan, A. 1994. "Savings in Germany." Pp. 38-55 in International Comparison of Household Saving, ed. by J. M. Poterba. Chicago, London: University of Chicago Press.

Cases, L. 1999. La consommation des ménages en 1997. Paris: INSEE.

Cecodhas 1995. Les européens et leur logement. Portrait statistique du logement dans les États membres de l'Union Européene. Paris: UNFOHLM.

Enquête Logement 1996/1997 1997. Tables from the research on CD. Paris: INSEE.

Eurostat 1998. Portrait Social de l'Europe 1998. Luxembourg: Office des publications officielles des Communautés européennes.

Ministerie van Volkshuisvesting, Ruimtelijke Ordening en Miliebeheer 1998. Den Haag: Ministerie VROM.

Pouquet, L., E. Maincent 1999. "Vers un modèle de consommation européen?" Problèmes politique et sociaux 816: 70-72.

Price of Housing in Hungary 1998. Budapest: Metropolitan Research Institute.

Regional Housing Indicators 1995. (Central and East Europe. Country: Slovenia). Budapest: Metropolitan Research Institute.

Tréquer, J. P. 1998. Le senior marketing: vendre et communiquer avec succés au marché des plus de 50 ans. Paris: Dunod.

Wilcox, S. 1999. Housing Finance Review 1999/2000. London: Joseph Rowntree Foundation. 